\title{
Feasibility Study Based on Social and Cultural Aspects in Public Health Center (Puskesmas) in Moyo Hilir Sub-district
}

\author{
Dwi Mardhia* \\ Faculty of Animal Husbandry and Fisheries, \\ Universitas Samawa \\ Sumbawa Besar, Indonesia \\ dwimardhia@gmail.com
}

\author{
Dedi Syafikri \\ Faculty of Animal Husbandry and Fisheries, \\ Universitas Samawa \\ Sumbawa Besar, Indonesia \\ fik.marine@gmail.com
}

\author{
Suprianto Suprianto \\ Faculty of Economic and Management, \\ Universitas Samawa \\ Sumbawa Besar, Indonesia \\ antobalong83@gmail.com
}

\begin{abstract}
Public health center (Puskesmas) is a first-level health service unit plays an important role in improving community health status. Decent puskesmas are a demand in community health development. This study aims is to analyze feasibility of pukesmas in Moyo Hilir sub-district based on social and cultural aspects. The method use in this study is an online survey through a questionnaire using google forms involving 85 respondents. Data analysis is descriptive qualitative. The survey results show that the sociocultural condition of the community in the form of needs and trust in health services by puskesmas is quite high. The existing puskesmas is considered to be inappropriate because there are 5 deficiencies namely land area, building structure, service support facilities, waste management, waste water treatment plant conditions and incinerator. $54 \%$ of respondents strongly agree, $33 \%$ agree, $7 \%$ disagree and $6 \%$ of respondents disagree with the relocation plan and new construction of the puskesmas Moyo Hilir. The planned relocation of the puskesmas to the new location is socially and culturally feasible.
\end{abstract}

Keywords - Feasibility study, Public health center, Puskesmas, Socio and cultural aspect

\section{INTRODUCTION}

Development in the health sector aims to provide health services that are easy, equitable and inexpensive [1]. Increased health services mean an increase the public health degree [2]. One of the government's efforts in the framework of equitable distribution of community health services is to provide health facilities that reach all levels of society in regions various [3]. The success rate of Sumbawa Regency's community health is influenced by healthy environment, health services, hereditary factors and healthy behavior. Among these four factors, health services have a very strategic role because health care is a very broad preventive, rehabilitation and educational health effort.

One form of efforts to bring health services closer to the Sumbawa Regency government is through the Technical Implementation Unit of the Community Health Center (UPT. Puskesmas). Puskesmas is a health facility that functions as a driver for health-oriented development, which provides direct services to the community [4]. Puskesmas is a technical implementation unit of the district/city health office in the sub-district area to carry out operational tasks of health development [5]. The puskesmas is responsible for organizing health development in its working area. As a public service facility, puskesmas maintain and enhance a healthy environment in accordance with standards and requirements [6]. As a health development provider, the puskesmas is responsible for organizing individual health efforts and public health efforts, which are viewed from the national health system as the first level of health services [7]. Development of puskesmas requires planning aimed at making development possible. Development of puskesmas requires a Feasibility Study (FS). FS is the result of analysis and explanation of the feasibility of all aspects that will underlie the establishment or development of a development activity [8]. Feasibility study activities need to be carried out related to technical and non-technical aspects including; location and building technical aspects, environmental and health aspects, socio-economic and cultural aspects and managerial management and organization of puskesmas which are finally summarized in a recommendation.

The Sumbawa Regency Government, through the Sumbawa District Health Office, is planning to relocate and construct a new Moyo Hilir puskesmas. The existing location of the puskesmas is in Moyo Mekar village and the relocation plan is to Berare village. One aspect of the study in a health center feasibility study is the social and cultural aspects related to community perceptions, acceptance or rejection of the puskesmas development plan. Puskesmas services in several places often get a lot of complaints from patients [9]. Complain or rejection is an inhibiting factor for the success of health development goals. Therefore, a Feasibility Study (FS) is needed to determine the feasibility of the realization of the plan so that there is a scientific study that can be used as a reference for the issuance of a permit to build a health center. This feasibility study activity is focused on the study of social and cultural aspects. This study aims is to analyze the feasibility of health centers in Moyo Hilir sub-district based on aspects of social and cultural feasibility.

\section{METHOD}

The study was conducted in Moyo Hilir Subdistrict, Sumbawa Regency, with respondents selected purposively consisting of UPT Moyo Hilir Puskesmas managers, Puskesmas patients, subdistrict head, Village Head, and community leaders, who were considered to be representatives of policy holders, actors and users of puskesmas services. The respondents of this study were 85 people spread in all villages (10 villages) in Moyo Hilir sub-district. Interview with respondents using the Google form instrument and in-depth interviews to get more complete information. Data analysis used descriptive qualitative method by using tabulation and narration to explain the feasibility of the new relocation and development plan of the Moyo Hilir puskesmas to the Berare village from its original location, in the Moyo Mekar village. The feasibility of social and cultural aspects is seen based on 
several variables, namely: (1) General description of the social and cultural conditions of the community, (2) Attitudes and perceptions of the community towards existing health services and facilities, (3) Attitudes and perceptions of the community towards the relocation and development plan Public health center.

\section{RESULT AND DISCUSSION}

\section{General Description of Social and Cultural Conditions in Communities relating to Health Aspects}

The condition of public health in the Moyo Hilir sub-district can be seen from the description of the number of patient visits to the downstream Moyo puskesmas as follows:

TABLE 1. NUMBER OF PATIENT VISITS TO MOYO HILIR HEALTH CENTER DETAILED BY VILLAGE IN 2018

\begin{tabular}{|c|c|}
\hline Village & Number of visits \\
\hline Serading & 684 \\
\hline Kakiang & 280 \\
\hline Moyo & 4578 \\
\hline Poto & 899 \\
\hline Berare & 0 \\
\hline Ngeru & 1093 \\
\hline Olat Rawa & 623 \\
\hline Batu Bangka & 1169 \\
\hline Moyo Mekar & 4145 \\
\hline Labuan ijuk & 426 \\
\hline Total & 1.114 \\
\hline
\end{tabular}

Source : [10]

The data shows that the people from Moyo Mekar and Moyo villages were the most patients who went to the Moyo Hilir puskesmas. While there are not as many other villages as the two villages. this is because the distance to the puskesmas is quite far for the villages in the far end of the Moyo Hilir subdistrict. The condition of the people of Moyo Hilir Subdistrict on their response when they felt unwell/sick based on the results of a survey conducted by the research team of 85 respondents from all villages, indicating their level of trust in health services at the Puskesmas was quite high. This is evidenced by the response of the community which states that when they are sick, the first thing they do first is to go directly to a health center with a percentage of $52 \%$. Whereas $38 \%$ of the people directly buy generic drugs that are sold in the market, $9 \%$ use traditional medicines/alternative medicine and $1 \%$ if the condition is severe, then go to the puskesmas.

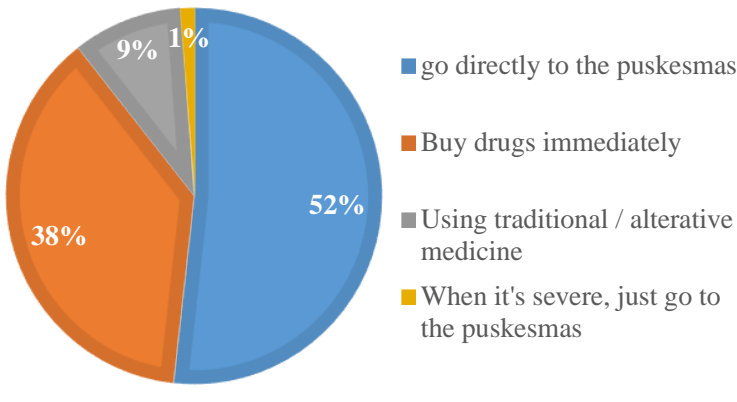

Fig. 1. First Actions When Ill

Judging from the frequency of respondents visiting health facilities, it is known that 27 people (32\%) who visited the puskesmas in the span of 1 time in 3 months, 23 people (27\%) visited the puskesmas only when sick, 18 people $(21 \%)$ visited the puskesmas in span of time once a year, 8 people (9\%) visit once in 6 months, 3 people $(4 \%)$ visit once a month, 2 people $(2 \%)$ visit 2 times a month and 4 people ( $5 \%$ ) others have never been treated at a puskesmas. The percentage of respondents' visit frequency can be seen in Figure 2.
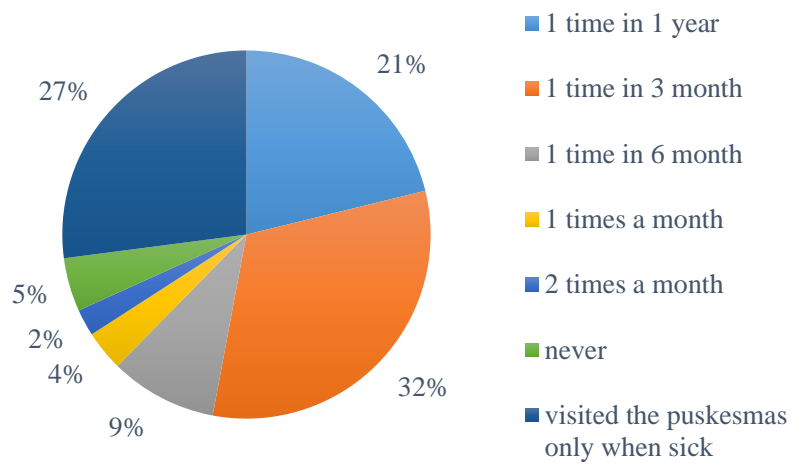

Fig. 2. Frequency of Community Visits to Moyo Hilir Health Center

Public perception of the cure rate of treatment at the health center showed that as many as 28 people $(33 \%)$ were very sure of being cured, 49 people $(58 \%)$ were quite sure of being cured, 5 people $(6 \%)$ were less sure and 3 people (3\%) were not sure of recover if treated at a puskesmas. More details can be seen in the following figure.

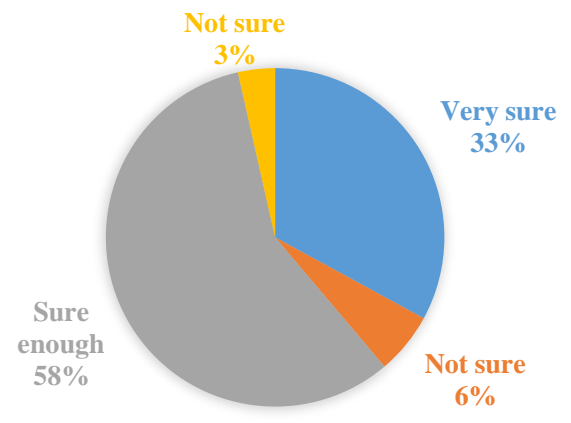

Fig. 3. Trust Levels of Community Healing for Puskesmas 


\section{Public Attitudes and Perceptions of Puskesmas Services and Facilities}

Based on the survey results it is known that the existing condition of Moyo Hilir puskesmas shows a number of problems namely most of the building structures are estimated to be unlikely to last for long because they are old buildings. Furthermore, in terms of location, the community assesses the location of the existing puskesmas in a floodprone environment because it is in the Moyo Hilir River flow path. Even in the cycle of 5 (five) years, puskesmas experience a large flood. In terms of the existing land area, it shows that currently the puskesmas will be difficult to develop, especially infrastructure development due to the narrow land area. Service support facilities such as waiting rooms, toilets, parking lots) are considered less in line with community expectations. Another problem that is no less important at the Moyo Hilir Health Center at the moment is the treatment of both solid and liquid waste where there is a wastewater treatment plant (IPAL) and incinerator (medical B3 waste incinerator) but it does not function at all. Therefore, the community places more hope in the downstream moyo puskesmas to be built primarily in terms of service facilities, sanitation and environmental cleanliness.

TABLE 2. PERFORMANCE INDICATORS OF EXISTING PUSKESMAS SERVICES

\begin{tabular}{|c|c|c|}
\hline No & Statement & $\begin{array}{l}\text { Perception of } \\
\text { respondents }\end{array}$ \\
\hline 1 & The number and quality of available human resources (especially nurses and doctors) is sufficient & Agree \\
\hline 2 & Land area or land of existing puskesmas (puskesmas currently available) is feasible & Not Agree \\
\hline 3 & $\begin{array}{l}\text { The existing structure of the puskesmas building still meets the requirements, is strong / sturdy and can last for the next } 10 \\
\text { years }\end{array}$ & Not Agree \\
\hline 4 & The types of services and services available at the puskesmas are in line with expectations & Agree \\
\hline 5 & Puskesmas service procedures are quite fast and straightforward & Agree \\
\hline 6 & The attendants are friendly and professional & Agree \\
\hline 7 & Services at the Puskesmas are provided by Puskesmas personnel according to their expertise & Agree \\
\hline 8 & The drugs available at the Puskesmas are quite complete & Agree \\
\hline 9 & The price / service tariff at the Puskesmas is affordable according to my ability & Agree \\
\hline 10 & Access to the existing Puskesmas (puskesmas currently available) is quite easy for me to reach & Agree \\
\hline 11 & Transportation infrastructure to the puskesmas location is available and feasible & Agree \\
\hline 12 & Supporting facilities (waiting rooms, toilets, parking, etc.) have met my expectations & Not Agree \\
\hline 13 & The puskesmas has separated medical and non-medical waste & Not Agree \\
\hline 14 & The puskesmas already has a wastewater treatment plant (IPAL) and is operating well & Not Agree \\
\hline 15 & The puskesmas has an incinerator (medical B3 waste incinerator) and operates well & Disagree \\
\hline
\end{tabular}

(Source: Data Analysis, 2020)

Based on the results of the analysis in table 2, there found 5 shortcomings of the existing health centers that are land area, building structures, service support facilities, waste management, WWTP conditions and incinerators. services, availability of human resources, availability of drugs according to the community is quite good. This illustrates that the community does not have a problem with the quality of service provided by the Puskesmas human resources, only that the condition of the existing Puskesmas buildings is very improper and that new relocation and development needs to be done.

\section{Public Attitudes and Perceptions of the New Relocation and Development Plan of Moyo Hilir Puskesmas}

The development of the Moyo Hilir puskesmas is based on how important health services are to the community and so that the community knows how important healthy living patterns are. The development of the Moyo Hilir puskesmas will also provide understanding that the development of the health sector cannot be separated from the concept of development of Indonesian society in general, especially in the Sumbawa Regency area. Therefore, the existence of Moyo Hilir puskesmas will assist the government in providing health services and promoting healthy lifestyles to give birth to a healthy and resilient generation.

Based on the results of a survey about the attitudes and perceptions of the community regarding the Moyo Hilir Public Health Center relocation plan, 54\% of respondents strongly agreed, $33 \%$ agreed, $7 \%$ of respondents said they disagreed and 6\% disagreed with the Moyo Hilir Puskesmas relocation plan. Percentage of respondents who agreed because of the condition of existing puskesmas that were already inadequate and the existence of several advantages of relocation puskesmas locations namely:

a) The available location is wider than before

b) A new, more representative, wider building will be built with better arrangement when compared to the existing puskesmas which are relatively narrow and often flooded given the location is directly adjacent to the Moyo river flow 
c) Located in a strategic location, namely in front of a [10] UPT Puskesmas, "Profil Tahun 2019," Sumbawa, 2019. road that is easily accessible from all corners of the Moyo Hilir District

The availability of new facilities and infrastructure is expected to increase or increase the quantity, quality and type of health services provided by puskesmas.

\section{CONCLUTION}

Relocation and Development of Moyo Hilir Health Center is mainly to meet the needs of adequate health infrastructure facilities in order to provide and improve basic health services to the community so that it can improve the health status of the Moyo Hilir District and Sumbawa District. Based on social and cultural analysis, the new relocation and development plan of the Moyo Hilir puskesmas is worthy of continuing to see the high percentage of approval and support from people who need a new puskesmas in a more representative location at $54 \%$ of respondents strongly agree and $33 \%$ agree with the relocation plan.

\section{ACKNOWLEDGMENT}

Special thanks to the Public health office (Dinas Kesehatan) Sumbawa district who has funded this research. Thanks also to the researchers of the PT. Asriguna Kreasi Samawa for his contributions and suggestions.

\section{REFERENCES}

[1] C. Anggraeny, "Imovasi Pelayanan Kesehatan," Kebijak. dan Manaj. Publik, vol. 1, no. 1, pp. 85-93, 2013.

[2] S. Ma'arif, "Kebijakan Desentralisasi dan Problema Kapasitas Layanan Kesehatan," J. Untirta, pp. 55-77, 2014.

[3] K. Winarno, M. Hasanbasri, and D. K. Sunjaya, "Evaluasi Kebijakan Pembangunan Puskesmas Pembantu di Provinsi Kalimantan Tengah,” J. Kebijak. Kesehat. Indones., vol. 02, no. 02, pp. 86-94, 2013.

[4] H. Adam, S. Arifin, R. Nurdiansyah, and W. Kusumadewi, "Studi Kelayakan Puskesmas Sawahan Untuk Puskesmas Rawat Inap," $J$. Pemerintahan, Pembang. dan Inov. Drh., vol. 1, no. 2, pp. 99-118, 2019.

[5] M. K. RI, "PERATURAN MENTERI KESEHATAN REPUBLIK INDONESIA NOMOR 43 TAHUN 2019 TENTANG PUSAT KESEHATAN MASYARAKAT," 2019.

[6] A. S. Rompas, P. Mekel, and M. Pandowo, "Evaluating Service Quality of Puskesmas Pineleng Using Importance Performance Analysis ( Ipa ) Menggunakan Importance Performance Analysis ( Ipa )," J. Berk. Ilm. Efisiensi, vol. 15, no. 05, pp. 66-75, 2015.

[7] R. Riyandani, "Studi Kelayakan Puskesmas Mulya Harja sebagai Syarat Didirikannya Puskesmas dengan Memperhatikan Kebutuhan MAsyarakat," Bogor, 2014.

[8] Kemenkes RI, "Pedoman Penyusunan Studi Kelayakan (Feasibility Study) Rumah Sakit," 2012.

[9] H. U. Sukanti, Sri, "Analisis Indeks Kepuasan Masyarakat (Ikm) Pada Pelayanan Publik Di Puskesmas Kalicacing Kota Salatiga," J. Ilm. Among Makarti, vol. 8, no. 15, pp. 1-15, 2015. 